\title{
The Effect of Moringa Oleifera Leaf Extract on Mean Platelet Volume and Neutrophil-to-Lymphocyte Ratio in Autoimmune Patients
}

\author{
Nurhasan Agung Prabowo ${ }^{1,4}$, Arief Nurudhin ${ }^{2}$, Ayuningdyah Chitra Buanantri ${ }^{3}$ \\ 1,2,3 Internal Medicine Department, Faculty of Medicine, Sebelas Maret University \\ ${ }^{4}$ Universitas Sebelas Maret Hospital \\ ${ }^{*}$ Corresponding author. Email: dr.nurhasan21@staff.uns.ac.id
}

\begin{abstract}
Background: Moringa oleifera is one of the promising novel treatments in autoimmune diseases through anti-inflammation and immunosuppression. Mean platelet volume and neutrophil-to-lymphocyte ratio are used to measure the degree of inflammation. This study aimed to identify the effect of Moringa oleifera leaf extract on the mean platelet volume and neutrophil-lymphocyte ratio in autoimmune patients. Research methods: This experimental study was conducted on 30 autoimmune patients consisting of 28 lupus patients and 2 rheumatoid arthritis patients of the rheumatology clinic at Moewardi General Hospital in JanuaryMarch 2019. The patient was grouped into two, the treatment and control groups. The patients were in the treatment group received 2 grams of Moringa oleifera leaf extract per day, while those in the control group received a placebo. The study was conducted for 4 weeks, concluded with an evaluation. MPV (mean platelet volume) and NLR (neutrophil-to-lymphocyte ratio) examination used a haemocytometer. Statistical analysis was performed using paired T-test and independent T-test. The p-value was considered significant when $\mathrm{p}<0.05$. Results: The results showed that Moringa oleifera leaf extract decreases MPV (delta MPV $=4.141 ; r=0.656 ; p$ - value $=0.02$ ) and Neutrophil-to- lymphocyte ratio (delta NLR $=4.1391 ; \mathrm{r} 0.489 ; \mathrm{p}$-value $=0.04$ ). Conclusion: The study revealed that Moringa oleifera leaf extract decreased mean platelet volume and neutrophil-to-lymphocyte ratio in autoimmune patients.
\end{abstract}

Keywords: Moringa oleifera extract, mean platelet volume, neutrophil-to-lymphocyte ratio, autoimmune patients

\section{INTRODUCTION}

Lupus is a chronic inflammatory autoimmune, Systemic erimatous lupus (SLE) is a multisystem disease caused by antibody production and deposition of complementary immune complexes which results in tissue damage [1]. Rheumatoid arthritis (RA) is a progressive and chronic inflammatory disease in symmetric peripheral polyarthritis [2].

Neutrophil-to-lymphocyte ratio (NLR) is calculated as the absolute count of neutrophils divided by the absolute count of lymphocytes. The mean platelet volume (MPV) is a platelet activation biomarker that has been recently correlated with disease activity in SLE and RA. Neutrophils will increase in inflammatory conditions, whereas the higher the degree of lupus, the more inflammation will occur. Meanwhile, the lymphocytes will decrease in active lupus due to lymphocyte apoptosis. It is partly because there are also anti-lymphocyte antibodies in SLE. MPV reflects the degree of inflammation and the role, function, and activity of platelets. NLR and MPV can be a marker of SLE disease activity and a marker of inflammation in SLE. The higher the NLR and MPV, the more severe the degree of
SLE disease activity and inflammation that occurs in SLE $[3,4,5]$.

The unclear pathogenesis of the disease and less optimal therapy can result in a high SLE and RA mortality rate. The current LES therapy is only to inhibit progression and prevent the severity of the disease. The absence of definitive cure therapy for SLE has made many research breakthroughs in the treatment of SLE. Moringa oliefera is one of the breakthrough therapies in SLE. Moringa oliefera (MO) Lam (moringa leaf) is a plant in the Moringaceae family, containing a variety of unique phytochemical groups that produce a spectrum of biological effects, especially anti-inflammatory [5].

Moringa oliefera has two mechanisms for inhibiting Lupus. It exhibits immunosuppressant properties by decreasing the number of CD4 T cells (T Helper cells) [6] with cell apoptosis pathways due to excessive calcium influx in cells (Zainal Path) [7]. In addition, Moringa oliefera will have an anti-inflammatory effect by inhibiting $\mathrm{nfK} \beta[8]$. The $\mathrm{nfK} \beta$ inhibition will cause a decrease in proinflammatory cytokines IL 6 , IL 1 , and TNF $\alpha$ so that tissue inflammation decreases [9]. Futhermore, Moringa Oleifera has been used to reduce the effect of rheumatoid arthritis. 
Moringa oleifera (wild type) exerted significant antiarthritic activity in rats and prevents complications of RA such as weight loss and anemia. Antiarthritic activity of M. oleifera may be due to the scavenging of free radicals, inhibition of protein denaturation, membrane stabilization and anti-trypsin activity of the extract [10].

MPV and NLR laboratory tests are easily available, cheap and easy to obtain.. This study aimed to identify the effect of Moringa oliefera leaf extract on the mean platelet volume and neutrophil-to-lymphocyte ratio in autoimmune patients.

\section{METHODS}

This research was conducted from January to July 2020 at the Moewardi Hospital in Surakarta. The inclusion criteria were SLE and RA outpatients. Exclusion criteria were patients with severe flare conditions, comorbid diabetes, kidney, heart, lung, and infection. Hematology examination used a hematology analyzer machine. The control group received a placebo, while the treatment group received a $2 \mathrm{~g}$ dose of Moringa oliefera leaf extract per day for 28 days. At the beginning oand after the treatment, blood data were taken on a routine basis to provide NLR and MPV.

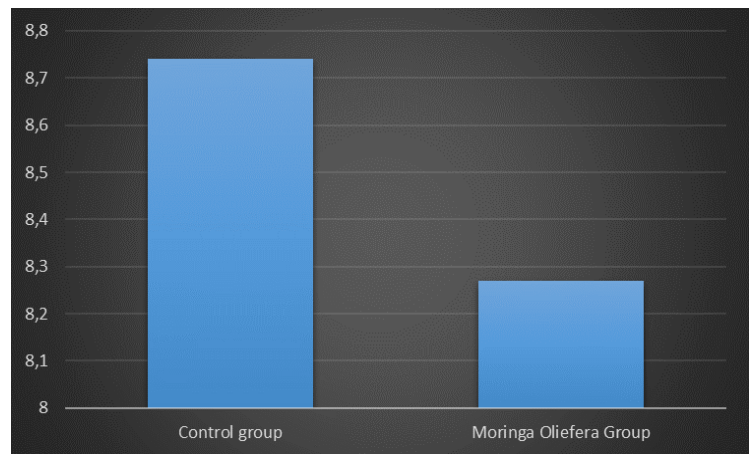

Figure 1. Effect of Moringa oleifera Leaf Extract on MPV

The obtained data were presented in mean value and standard deviation. The Normality test was performed using the Shapiro-Wilk test and variant homogeneity test was performed using Levene's test and the F Anova test followed by the Least Significant Difference (LSD) posthoc test for data with normal and homogenous distribution and Kruskal-Wallis followed by the Mann-Whitney test for data with abnormal or non-homogeneous distribution. The significance level was at $p<0.05$. The protocol fot the study was approved by the ethical and research committee. Data were collected only after the patients informed and provided written consent. Ethical clearance for the study was obtained from the Health Research Ethics Committee of Universitas Sebelas Maret (No.074/UN27.06.6.1/KEPK/EC/2020).

\section{RESULTS}

Table 1. Hematology Analysis Of Research Subjects

\begin{tabular}{cccccc}
\hline Variable & \multicolumn{2}{c}{ Control } & \multicolumn{2}{c}{ MO } & p \\
& Mean & SD & Mean & SD & \\
\hline Leucocyte & 8.28 & 1.67 & 9.73 & 2.64 & 0.082 \\
Thrombocyte & 314.81 & 55.67 & 312.46 & 68.67 & 0.920 \\
Erythrocyte & 4.51 & 0.61 & 4.52 & 0.41 & 0.955 \\
MCV & 84.01 & 5.86 & 81.92 & 5.01 & 0.318 \\
MCH & 27.4 & 2.78 & 26.47 & 3.06 & 0.380 \\
MCHC & 32.60 & 1.47 & 32.22 & 2.26 & 0.592 \\
RDW & 14.11 & 1.99 & 14.14 & 1.63 & 0.970 \\
MPV & 8.74 & 1.55 & 8.27 & 2.05 & 0.485 \\
PDW & 20.44 & 13.95 & 20.31 & 13.19 & 0.808 \\
Eosinofile & 0.98 & 1.23 & 2.31 & 2.38 & 0.083 \\
Basofil & 0.50 & 0.25 & 0.61 & 0.42 & 0.391 \\
Neutrphyl & 68.83 & 12.28 & 69.14 & 9.86 & 0.904 \\
Limfochyt & 22.73 & 9.81 & 21.29 & 7.91 & 0.672 \\
Monosit & 6.44 & 2.11 & 5.93 & 1.79 & 0.492 \\
\hline
\end{tabular}

Table 2. Effect of Moringa oleifera Leaf Extract on NLR and MPV in Autoimmune Patients

\begin{tabular}{ccccccc}
\hline Variable & \multicolumn{2}{c}{ Control } & \multicolumn{2}{c}{ MO } & \multicolumn{2}{c}{ Correlation } \\
& Mean & SD & Mean & SD & $\boldsymbol{r}$ & $\boldsymbol{P}$-value \\
\hline NLR & 3.23 & 1.23 & 3.11 & 1.05 & -0.489 & 0.04 \\
MPV & 8.74 & 1.55 & 8.27 & 2.05 & -0.656 & 0.02 \\
\hline
\end{tabular}

This study found that Moringa oleifera could reduce the NLR in lupus patients with a correlation coefficient of 0.489 and a P-value of 0.04. Besides, Moringa oleifera also reduce the value of MPV in autoimmune patients with a correlation coefficient of -0.656 and a $\mathrm{P}$-value of 0.02 .

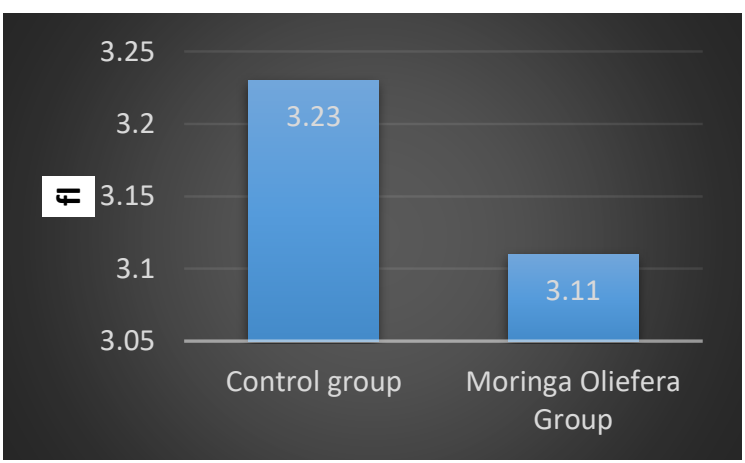

Figure 2. Effect of Moringa oleifera Leaf Extract on NLR

\section{DISCUSSION}

In this study, Moringa oleifera which has been known to have anti-inflammatory, antioxidant, and immunomodulatory effects, has been proven to reduce dsDNA levels in conditions of lupus nephritis and to maintain renal histopathological conditions in lupus nephritis. This is in line with previous studies which found that glucosinolate and isothiocyanates have a strong inhibitory effect on NO (Nitric Oxide) production. Further, the study found that it could reduce insulin, leptin, resistin, cholesterol, interleukin-1ß (IL-1ß), tumor necrosis factoralpha (TNF $\alpha$ ), and glucose-6-phosphatase in diabetic mice. Thus, it can be said that isothiocyanate compounds may be 
the main bioactive ingredients that have anti-diabetic activity and anti-inflammatory responses [11].

Flavonoids, which include quercetin, kaempferol glucoside, and flavonoid malfates, show anti-inflammatory activity through inhibition of NO production in LPS macrophages [11]. Many previous studies have established the inhibitory effects of Moringa oleifera on NO, VEGF, TNF $\alpha$, IL-2, IL-1ß, IL-6, glucose-6-phosphatase, insulin, leptin, resistin, and cholesterol [11, 12, 13]. The most common pathway, which is considered a prototypical proinflammatory signaling pathway and a parent transcription factor, is mediated by NF-kß [14].

$\mathrm{NF}-\kappa \mathrm{B}$ is the main transcription factor that plays an important role in controlling the inflammatory response. NF- $\kappa B$ activation modulates signal controller which switches the pro-inflammatory gene transcription response. Toll-like receptors (TLR) and cytokines, such as TNF and IL-1, regulate the transcription of other pro-inflammatory genes. These NF-кB target genes are needed to activate immunity and destroy pathogens. In a state of unstimulated cells, the NF- $\mathrm{NB}$ protein is in the cytoplasm which is held by an inhibiting molecule called I- $\kappa \mathrm{B}$. The role of NF- $\kappa \mathrm{B}$ indicates the existence of opposing functions. However, $\mathrm{NF}-\kappa \mathrm{B}$ is important for activating proinflammatory genes, which are important for improving inflammation and protection from apoptosis. Conversely, excessive activation of in vivo NF- $\kappa \mathrm{B}$ will cause death, This is because the cellular level excessive activation of $N F-\kappa B$ will inhibit activation of the immune response and increase sensitivity to apoptosis [8]. Moringa oliefera has an anti-inflammatory effect by inhibiting nfK $\beta$ [9]. NfK $\beta$ barriers cause a decrease in proinflammatory cytokines IL 6, IL 1, and TNF $\alpha$ so that network inflames are reduced [9].

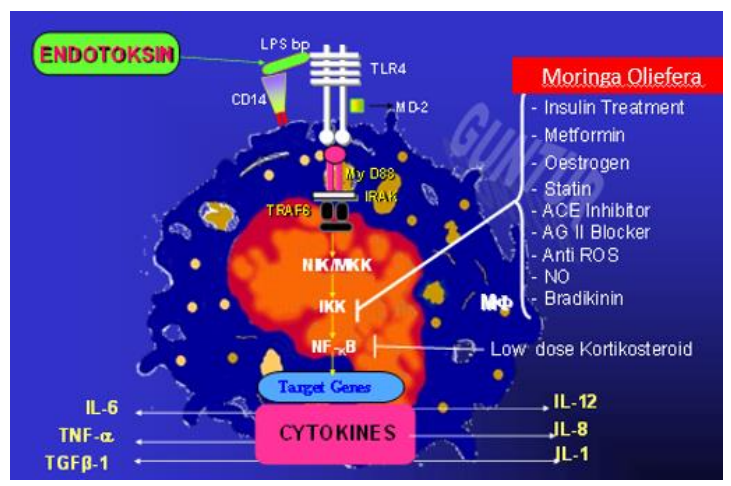

Figure 3. Effect of Moringa Oliefera by inhibiting nfK $\beta$ [9]

Fathir et al. showed that the dose of Moringa oliefera leaf extract has 2 effects on T cells CD4 T lymphocytes/T helper cells namely low doses that are immunostimulant and high doses which cause immunosuppression. The increase in the number of CD4 + T cells is caused by the presence of an active substance in Moringa leaf extract which functions as an immunostimulant against the immune system. Active substances that are thought to have a role as immunostimulants are saponins and flavonoids. Saponins and flavonoids are thought to be able to induce an increase in the secretion of cytokines involved in the process of CD4 $+\mathrm{T}$ cell activity [15].

Saponins and flavonoids are substances that play a role in triggering up helper $\mathrm{T}$ cell regulation by stimulating increased production of interleukin 2 (IL-2) cytokines. Cytokine IL-2 is needed by CD4 + T cells to differentiate in the Heper 2 (Th2) and Th1 T cell subsets [16]. In addition to functioning as an immunostimulant, Moringa leaf extract can function as an immunosuppressant. This can be seen in the administration of high doses of Moringa leaf extract which causes an increase in the number of CD4 + T cells which is lower than the low dose administration. In LES, the most important effect is high doses which and causes immunosuppressants effect through the lymphocyte apoptosis pathway.

T lymphocytes are the main mediator of immune disease. Therefore, modification of $\mathrm{T}$ cell activation will be a tool for immune-chained diseases. A study [6] found that Moringa oleifera had an inhibitory effect on $\mathrm{T}$ cell proliferation. This inhibitory effect was statistically different between $200 \mathrm{mg} / \mathrm{kg}$ and $400 \mathrm{mg} / \mathrm{kg}$ but statistically did not differ between $400 \mathrm{mg} / \mathrm{kg}$ and $600 \mathrm{mg} / \mathrm{kg}$. The inhibiting effect of Moringa oleifera at $400 \mathrm{mg} / \mathrm{kg}$ was not caused by cytotoxicity. The study [6] showed that administration of Moringa oliefera in mice increased intracellular calcium ion levels in lymphocyte cells and caused the death of lymphocyte cells by apoptosis [6].

Large increases in free $\mathrm{Ca} 2+$ in intracellular space are very toxic [7], which result in:

1. An increase in $\mathrm{Ca} 2+$ activating the catabolic enzyme calpain 1 which can result in the degradation of several neuronal protein structures (neurofilament peptide, tubulin, and spectrin).

2. Increased $\mathrm{Ca} 2+$ activating phospholipase which causes damage from cell membranes, then released of arachidonic acid which produces oxygen free radicals and forms superoxide enzymes, and leads to growth factors withdrawal.

3. Increased $\mathrm{Ca} 2+$ with the glycerol produced activates protein kinase $\mathrm{C}$, which further increases the $\mathrm{Ca} 2+$ influx.

4. Increased $\mathrm{Ca} 2+$ influx stimulating more glutamate release, resulting in neurotoxic glutamate.

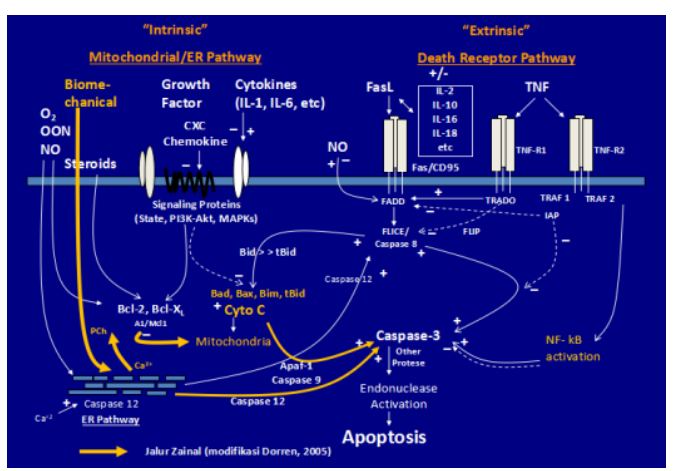

Figure 4. Intracellular calcium ions cause cell apoptosis according to the Zainal pathway [7]. 
Referring to the Zainal pathway, high Calcium ions in lymphocytes will activate apoptosis. When passing through the cell membrane, $\mathrm{Ca} 2+$ activates the phospholipase $\mathrm{C}$ enzyme, which is able to phosphorylate phosphatidylinositol 1.4 biphosphate (PIP-2) to IP-3 and produce glycerol. IP-3 enters the cytosol and attaches to the surface of the endoplasmic reticulum, which results in the opening the $\mathrm{Ca} 2+$ channel and immediately circulates $\mathrm{Ca} 2$ + into the cytosol so that $\mathrm{Ca} 2+$ in the cytosol increases. It also activates phospholipase-A2. Phospholipase-A2 affects phosphatidylcholine to Lysophosphatidylcholine and arachidonic acid. Lysophosphatidylcholine affects the fluidity of cell membranes so that $\mathrm{Ca} 2+$ will enter from outside the cell to the cytosol. It results in higher levels of $\mathrm{Ca} 2+$ accumulation in the cytosol. Excessive accumulation of $\mathrm{Ca} 2+$ in the cytosol will bind calcineurin protein to form a calcineurin-Ca2 + complex, which can stimulate transcription activation of bad protein, which then affects PT pore on the open mitochondrial wall. The opening of PT pore results in the release of cytochrome $\mathrm{C}$ from mitochondria to the cytosol then activates apaf-1 followed by Caspase activation and subsequent apoptosis [7].

This study is in line with previous research [18] conducted in Malang which found that in vitro MO has activity as an immunomodulator through its active compounds, such as saponins and flavonoids, which act as immunostimulants on CD4 + (T helper cells) and CD4 + (cytotoxic T cells), as well as B220 + cell markers. Previous studies revealed that administration of low-dose Moringa leaf extract can increase the cell counts of T CD4 + and CD8 $+\mathrm{T}$ cells in all groups of mice but high doses of Moringa leaf extract will cause immunosuppression $[15,18]$. The current study utilized the immunosuppression effect on Moringa oliefera because it used a high dose of $500 \mathrm{mg} / \mathrm{kgBB}$. Tan et al in 2015 proved that Moringa oliefera was able to suppress IL 10 and IL 6 in autoreactive B cells [16]. As the pathogenesis of lupus, it will help suppress the formation of antidsDNA antibodies which are specific markers of damage in LES

This study proved that Moringa oleifera could significantly reduce disease activity in mice of the lupus model. This result is inseparable from the antiinflammatory function of Moringa oliefera which has been proven in some previous studies $[11,13,17]$. The result is also in line with some other studies on the protective effects of Moringa oliefera in the kidneys. Moringa oliefera leaf extract had a protective effect on rabbits induced with gentryin nephrotoxic substances [19]. Furthermore, a previous study [19] have proven that Moringa oliefera can prevent nephrotoxicity in Wistar rats that are induced by nickel. Both studies state that the protective effects of kidney in Moringa oliefera are primarily based on the antiinflammatory effects possessed by Moringa oliefera $[19$, 20]. These results were also in line with the study that demonstrated that $M$. oleifera hydroethanol bioactive leaves extract exhibited a remarkable anti-inflammatory effect on LPS induced inflammation in macrophages. Bioactive extract of $M$. oleifera effectively suppressed iNOS and COX-2 protein expression and also the production of NO and PGE2 stimulated by LPS. Moreover, it decreased the pro-inflammatory cytokines production (TNF- $\alpha, \mathrm{IL}-1 \beta$, and IL-6) induced by LPS in macrophages, and the level of IL-10 was increased through suppression of signaling cascades leading to the activation of NFKB-p65. Futhermore, it is suggested that the anti-inflammatory activity from bioactive compounds contained in $M$. oleifera hydroethanolic bioactive leaves extract could promote effective treatment to manage the inflammatory disorder [21].

This study showed that the administration of Moringa oliefera therapy and beyond standard therapy would reduce the value of MPV and neutrophil in autoimmune patients. Thus, further research to identify the Moringa oliefera as a safer drug for SLE and RA patients with limited side effects is needed.

\section{CONCLUSION}

The study demonstrated the effect of Moringa oliefera leaf extract in reducing mean platelet volume and neutrophil-to-lymphocyte ratio in autoimmune patients.

\section{AUTHORS' CONTRIBUTIONS}

Data gathering and idea owner of this study, Study design, Data gathering, Writing and submitting manuscript, Editing and approval of final draft, all events done by all the authors. All authors read and approved the final manuscript.

\section{ACKNOWLEDGMENTS}

The authors acknowledge the contribution of all research assistants involved in the collection of data. The authors express their profound gratitude to all participants in the study.

\section{REFERENCES}

[1] Tutuncu, "The Definition and Classification of Systemic Lupus Erythematosus," in Wallace DJ, Bevra $\mathrm{HH}$ (Ed.), DUBOIS Lupus Erythematosus and Related Syndromes, Philadelpia: Saunders, vol. 8, pp. 25, 2013.

[2] Kasner. D. L.. \& Harrison. T. R. (2005). Harrison's nrincinles of internal medicine. New York: McGrawHill, Medical Pub. Division

[3] Y. Wu, Y. Chen, X. Yang, L. Chen, Yang, "Neutrophilto-lymphocyte ratio (NLR) and platelet-to-lymphocyte ratio (PLR) were associated with disease activity in patients with systemic lupus erythematosus," Int Immunopharmacol, vol. 36, pp. 94-99, July 2016.

[4] M. Soliman, M. Sherif, M. Ghanima, A. El-Badawy, "Neutrophil to Lymphocyte and Platelet to Lymphocyte Ratios in Systemic Lupus Erythematosus: Relation With Disease Activity and Lupus Nephritis," Reumatol Clin, vol. 18, August 2018.

[5] J. Ray, J. Wolf, \& N. Mowa, "Moringa oleifera and inflammation: A mini-review of its effects and mechanisms," Acta Horticulturae, pp. 317-330. https://doi.org/10.17660/ActaHortic.2017.1158.36., 2017.

[6] S. Attakpa, A. Bertin, W. Chabi, M. Ategbo, B. Seri, \& A. Khan, "Moringa oleifera-rich diet and T cell calcium signaling in spontaneously hypertensive rats," Physiological Research, vol. 66(5), pp. 753-767, 2017.

[7] A. Zainal, Reumatologi Klinis Praktis, Surakarta: UNS Press, 2009. 
[8] L. Berkovich, G. Earon, I. Ron, A. Rimmon, A. Vexler, \& S. Lev-Ari, "Moringa Oleifera aqueous leaf extract down-regulates nuclear factor-kappaB and increases cytotoxic effect of chemotherapy in pancreatic cancer cells,". BMC Complementary and Alternative Medicine, vol. 13(1), pp. 212. https://doi.org/10.1186/1472-6882-13-212, 2013.

[9] H. Ahmad, SIRS dan Sepsis: Pedoman dan tata laksana. Surakarta: UNSpress, 2003.

[10] Saleem A, Saleem M, Akhtar M. Antioxidant, antiinflammatory and antiarthritic potential of Moringa oleifera Lam: An ethnomedicinal plant of Moringaceae family. South African Journal of Botany. 2019; 246-256

[11] C. Waterman, P. Rojas-Silva, B. Tumer, P. Kuhn, J. Richard, S. Wicks, et al.,"Isothiocyanate-rich Moringa oleifera extract reduces weight gain, insulin resistance, and hepatic gluconeogenesis in mice," Molecular Nutrition \& Food Research, vol. 59(6), pp. 1013-1024. https://doi.org/10.1002/mnfr.201400679, 2015.

[12] C. Coliccio, T. Ohashi, A. Brunson, \& S. Jesmin, "Moringa oleifera's Whole Methanolic Extract Attenuates Levels of Pro-inflammatory Markers in the Cervix of Preterm Labor Mice Models," The FASEB Journal, vol. 29 (1), pp. 721- 742, 2015.

[13] S. Fitch, Moringa oleifera whole methanolic leaf extract attenuates levels of angiogenic factors in the cervix of preterm labor mice models, Appalachian State University, 2016.

[14] T. Lawrence, "The Nuclear Factor NF- B Pathway in Inflammation," Cold Spring Harbor Perspectives in Biology, vol. 1(6), a001651-a001651. https://doi.org/10.1101/cshperspect.a001651,2009.

[15] A. Fathir, M. Rifai, \& Widodo, "Activity of aqueous leaf extract of horseradish tree on helper t- cell and cytotoxic t- cell in mice infected with salmonella thypi," Jurnal Veteriner vol. 15, pp 114-122, March 2014.

[16] K. Abbas \& Lichman, Basic Imunology (5th ed.). Philadelpia: Elsevier, 2011.

[17] S. Tan, P. Arulselvan, G. Karthivashan, \& S. Fakurazi "Moringa oleifera Flower Extract Suppresses the Activation of Inflammatory Mediators in Lipopolysaccharide-Stimulated RAW 264.7 Macrophages via NF- $\kappa$ B Pathway," Mediators of Inflammation, $\quad \mathrm{pp}$. 1-11. https://doi.org/10.1155/2015/720171, 2015.

[18] I. Rachmawati \& M. Rifa'i, "In Vitro Immunomodulatory Activity of Aqueous Extract of Moringa oleifera Lam. Leaf to the CD4 +, CD8+ and B220+ Cells in Mus musculus," The Journal of Experimental Life Sciences, vol. 4(1), pp. 15-20. https://doi.org/10.21776/ub.jels.2014.004.01.03, 2014.

[19] M. Ouédraogo, A. Lamien-Sanou, N. Ramdé, S. Ouédraogo, P. Zongo, I. Guissou, et al., "Protective effect of Moringa oleifera leaves against gentamicininduced nephrotoxicity in rabbits,"Experimental and Toxicologic Pathology, vol. 65(3), pp. 335-339. https://doi.org/10.1016/i.etp.2011.11.006, 2013.

[20] S. Adeyemi, \& C. Elebiyo, "Moringa oleifera Supplemented Diets Prevented Nickel-Induced Nephrotoxicity in Wistar Rats," Journal of Nutrition and Metabolism, pp. 1-8. https://doi.org/10.1155/2014/958621, 2014.

[21] Fard MT, Arulselvan P, Karthivashan G, Adam SK, Fakurazi S. Bioactive extract from moringa oleifera inhibits the pro-inflammatory mediators in lipopolysaccharide stimulated macrophages. Phcog Mag 2015;11:556-63 